\title{
Prevalence of smoking among high- school students of Tehran in 2003
}

G. Heydari, ${ }^{1}$ H. Sharifi, ${ }^{1}$ M. Hosseini ${ }^{2}$ and M.R. Masjedi ${ }^{1}$

$$
\text { غعلام رضا حيدري، هومن انتار التدين بين طلاب المدارس الثانوية في طهر ان، } 2003
$$

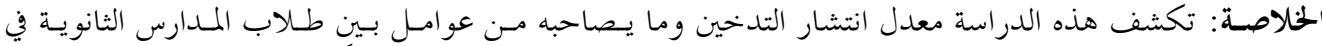

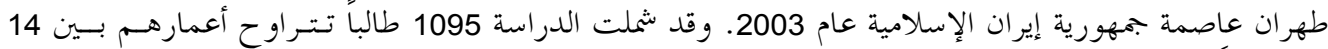

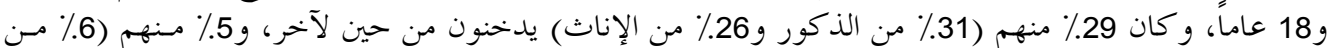

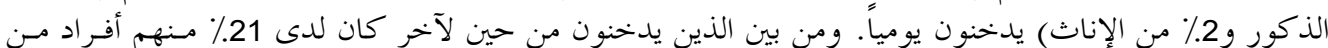

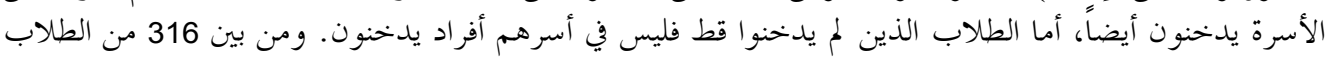

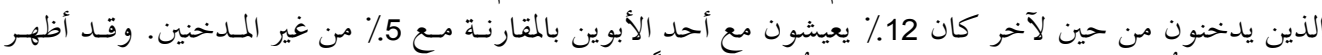

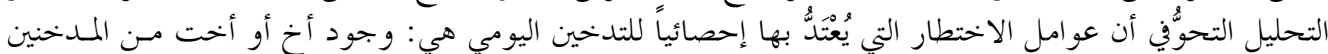

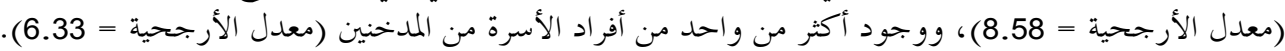

ABSTRACT This study in 2003 determined the prevalence of smoking and its associated factors among high-school students in Tehran, Islamic Republic of Iran. Out of 1095 students aged 14-18 years, $29 \%$ (31\% boys, $26 \%$ girls) were occasional and $5 \%(6 \%$ boys and $2 \%$ girls) daily smokers. Among occasional smokers, $21 \%$ had family members who also smoked, whereas for students who had never tried smoking, no family members smoked. Of 316 occasional smokers, $12 \%$ lived with a single parent compared with only $5 \%$ of never smokers. Regression analysis showed that significant risk factors for daily smoking were: having a brother or sister who smokes $(O R=8.58)$ and having more than 1 family member who smokes $(\mathrm{OR}=6.33)$.

Prévalence du tabagisme chez les élèves du deuxième cycle de l>enseignement secondaire à Téhéran en 2003

RÉSUMÉ Cette étude, menée en 2003, a déterminé la prévalence du tabagisme et des facteurs associés à celui-ci chez les élèves du deuxième cycle de l'enseignement secondaire à Téhéran (République islamique d'Iran). Sur 1095 élèves âgés de 14 à 18 ans, 29\% (31\% de garçons, 26\% de filles) étaient des fumeurs occasionnels et $5 \%$ (6\% de garçons, $2 \%$ de filles) des fumeurs réguliers. L'entourage familial de $21 \%$ des fumeurs occasionnels comptait au moins un membre fumeur, tandis qu'on ne recensait aucun fumeur dans celui des élèves n'ayant jamais fumé. Sur les 316 fumeurs occasionnels, $12 \%$ vivaient dans une famille monoparentale contre $5 \%$ pour les élèves n'ayant jamais fumé. Selon l'analyse de régression, les facteurs de risque significatifs du tabagisme régulier sont la présence d'un frère ou d'une sœur fumeurs $(O R: 8,58)$ et la présence de plus d'un fumeur parmi les membres de la famille (OR : 6,33).

\footnotetext{
${ }^{1}$ Tobacco Control Unit, National Research Institute of Tuberculosis and Lung Disease, Shaheed Beheshti University of Medical Sciences, Tehran, Islamic Republic of Iran (Correspondence to G. Heydari: ghrheydari@nritld.ac.ir).

${ }^{2}$ Department of Epidemiology and Biostatistics, Tehran University of Medical Sciences, Tehran, Islamic Republic of Iran.

Received: 19/06/05; accepted: 22/11/05
}

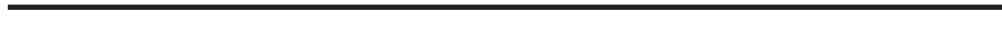




\section{Introduction}

Cigarette smoking is the foremost cause of preventable death worldwide [1]. Smoking is responsible for $30 \%$ of deaths of people aged between $30-50$ years of age and 12\% of total deaths [2]. At present, cigarette smoking takes the lives of about 5 million people per year. With this continuing trend, this figure will reach 10 million in the next 20 years, with 7 million deaths occurring in developing countries [3].

If regular cigarette smoking is started at a very young age, e.g. in early teens, there is a $50 \%$ chance of early death as a result of cigarette-related mortality [4]. Smokers who cease smoking at a younger age are safe from all smoking-related complications. It is notable that, the younger the age at which smoking is initiated, the greater is the chance of becoming a heavy smoker, dying of cigarette-related diseases and suffering from stroke or lung cancer at a younger age [5]. As compared to nonsmoker children, those that smoke even a few cigarettes per week suffer more coughs, common colds and ear infections. The lungs of a 16-year-old teenager who smokes 20 cigarettes/day is identical to a 28-year-old nonsmoker adult [6]. It has been noted that young individuals become addicted to cigarettes after only few cigarettes (for example less than 5 cigarettes) [4].

It has been demonstrated in different studies that young people consider smoking as a way of fighting and overcoming their problems and increasing their self-assurance and self-confidence $[7,8]$. In many industrialized countries, efforts are being made to educate children before the age at which they start smoking. Most elementary schoolchildren, between the ages of 5 to 11 years, are strongly opposed to smoking. However, by the ages of 12 and 13 years, pressure from peers and older classmates becomes increasingly difficult to resist. If friends or older children smoke at school, younger children tend to join them [8] and if the parents smoke, their children are also more likely to become smokers.

In the Islamic Republic of Iran, young people form a high proportion of the population and are therefore an important target for tobacco control and prevention programmes [9]. The aim of this study was to evaluate factors affecting the tendency towards cigarette smoking in young adults in Tehran city, Islamic Republic of Iran. High-school students were selected for this research because more than $60 \%$ of smokers start smoking by the age of 15 years according to the national health survey of the Iranian Ministry of Health in 1991 [10].

\section{Methods}

This was a cross-sectional descriptive study carried out over a 12-week period from mid-October 2003 to mid-February 2004. The total number of high-school students in Tehran is about 150 000. After obtaining consent approval for the questionnaire by the research centre at the Ministry of Education and, 5 districts (nos. 1, 2, 4, 14 and 19) were randomly chosen from the 19 district offices of the Ministry of Education using Epi-info, version 6 software. Using random numbers, 10 high schools were selected in each district and each school, 1 classroom was selected. The number of students per class varied from 80 to 110 . Out of 1119 students selected, 1095 questionnaires were available for analysis (98\% response rate).

After an explanation by 2 physicians who were part of the research team (1 male for boys and 1 female for girls), the students self-completed a questionnaire anonymously in a calm environment, without the presence of the school authorities. 
The questionnaire was prepared according to the World Health Organization (WHO) Global Youth Tobacco Survey (GYTS) questionnaire [11], which has been previously validated. Data were collected about: demographic information, history of daily or occasional cigarette smoking, reasons for smoking and which members of the family were smokers.

Data were entered into SPSS, version 11.5 software for analysis. In a logistic regression analysis smoking in family members and living with parents were included in the model. Crude and relative frequencies were calculated. To analyse the correlation between the variables, the chi-squared test (with significance at $P<0.05$ ) was used.

\section{Results}

There were 1095 high-school students, including 712 boys (65\%) and 381 girls (35\%) (data on sex was missing for 2). The age range was 14-18 years and the mean age was 16.7 years.

A total of 316 (29\%) students were occasional smokers (95\% CI: 26\%-32\%); 219 boys (31\%) (95\% CI: 27.4\%-34.3\%) and
97 girls (26\%) (95\% CI: 21.1-30.1) (not significant). There were 49 students (5\%) who used cigarettes every day (95\% CI: 3\%-6\%), 43 boys (6\%) (95\% CI: 4.6-8.1) and 6 girls (2\%) (95\% CI: $0.6 \%-3.4 \%)(P$ $<0.001)$.

The smoking status of the family members was studied (Table 1). Among the 316 occasional smokers, $12 \%$ had more than 1 other family members who also smoked, whereas in the students who had never smoked only $4 \%$ had 1 or more family member who smoked $(P<0.0001)$. Of the 49 students who smoked every day, $14 \%$ had a brother or a sister who smoked regularly compared with only $3 \%$ of those who did not smoke every day $(P<0.0001)$ (Table 1).

Of the occasional smokers, 279 (88\%) lived with both their parents, compared with 743 (95\%) of never-smokers. Thus, significantly more occasional smokers lived with a single parent (due to the death of a parent or separation) compared with neversmokers (12\% versus 5\%) $(P<0.0001)$. Of the students who smoked daily, only 2 (4\%) lived with both of their parents while 4 (8\%) lived with a single parent (not significant).

\begin{tabular}{|c|c|c|c|c|c|c|c|c|}
\hline \multirow{3}{*}{$\begin{array}{l}\text { Smoking in } \\
\text { family } \\
\text { members }\end{array}$} & \multicolumn{4}{|c|}{$\begin{array}{l}\text { Occasional smoking } \\
\text { among students }\end{array}$} & \multicolumn{4}{|c|}{$\begin{array}{c}\text { Daily smoking } \\
\text { among students }\end{array}$} \\
\hline & \multicolumn{2}{|c|}{ Yes } & \multicolumn{2}{|c|}{ No } & \multicolumn{2}{|c|}{ Yes } & \multicolumn{2}{|c|}{ No } \\
\hline & No. & $\%$ & No. & $\%$ & No. & $\%$ & No. & $\%$ \\
\hline None & 165 & 52 & 534 & 69 & 18 & 37 & 684 & 65 \\
\hline Father & 83 & 26 & 178 & 22 & 13 & 26 & 248 & 24 \\
\hline Mother & 10 & 4 & 13 & 2 & 1 & 2 & 23 & 2 \\
\hline Brother/sister & 19 & 6 & 19 & 3 & 7 & 15 & 31 & 3 \\
\hline $\begin{array}{l}\text { More than } 1 \\
\text { smoker }\end{array}$ & 39 & 12 & 35 & 4 & 10 & 20 & 60 & 6 \\
\hline Total & 316 & 100 & 779 & 100 & 49 & 100 & 1046 & 100 \\
\hline
\end{tabular}

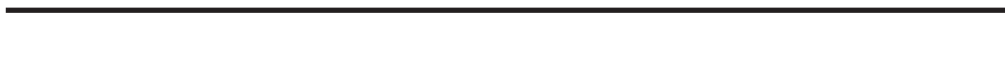


By using logistic regression analysis and excluding interventional factors, the most important predictive factors for occasional cigarette smoking in this group of adolescents were: presence of more than 1 family member who smokes (OR = 3.66; 95\% CI: 3.0-6.8); a brother or sister who smokes (OR = 2.96; 95\% CI: 2.0-7.7); living with single parent (OR $=2.5$; 95\% CI: 2.1-4.4). The most important predictive factors for daily smoking were: having a brother or sister who smokes $(\mathrm{OR}=8.58$; 95\% CI: 6.1-10.0) and having more than 1 family member who smokes $(\mathrm{OR}=6.33$; $95 \% \mathrm{CI}$ : 4.2-8.5).

\section{Discussion}

In this research, $29 \%$ of high-school students reported smoking cigarettes occasionally. In the GYTS study conducted in 1999 among the youth of 13 countries, occasional smoking was reported by between $10 \%-$ $33 \%$ of young people [12]. Also it was demonstrated in this study that the prevalence of occasional smoking among the teenagers of industrialized countries was greater than other countries [12]. Another study of male high-school students of Isfahan during 1988-89 showed that $22.5 \%$ were smokers and their first smoking experience was between the ages of 10-13 years [13]. However, in the Iranian national health survey performed from 1991-99, the prevalence of cigarette smoking had declined from $14.3 \%$ to $12.5 \%$ [10]

In our research the prevalence of daily cigarette smoking among this group of 14-18-year-olds was greater in boys than girls ( $6 \%$ versus $2 \%$ ), although among the students that smoked occasionally, the proportions were more similar (31\% versus $26 \%)$. This finding shows that the risk of trying cigarette smoking is similar in boys and girls, but boys in this age group are more likely to become dependent on smoking. Higher rates of smoking among adult males compared with females has been seen in studies in Egypt (20\% versus 5\%) [11] and in other Mediterranean countries in Europe, North Africa and the Middle East (60\% versus 20\%) [14]. In another study of the high-school students in Tehran, the prevalence of occasional smoking in boys and girls were $35 \%$ and $27 \%$ respectively [15].

There was a significant statistical relationship between cigarette smoking and the lifestyle of the students i.e. living with both parents or a single parent. We can hypothesize that living in a supportive and friendly family environment is a significant factor in preventing smoking in youth. We also observed that more students who had tried smoking had family members who also smoked compared with those that never smoked. This suggests that imitation plays an important role in the initiation of smoking in teenagers [16].

These findings were confirmed in the regression analysis, as the significant predictive factors for smoking were presence of more than 1 smoker among the family members, having a brother or sister that smokes and living with a single parent. Therefore, it can be concluded that family environment is an important factor influencing the smoking behaviour of adolescents.

In summary, the overall reported prevalence of occasional cigarette smoking among 14-18-year-olds in Tehran (29\%) is not especially high compared with figures reported from other countries. However, due to the large number of occasional smokers who will become addicted to cigarettes in the future and because of the limited health education and prevention programmes addressing smoking in the Islamic Republic 
of Iran, this figure is concerning. Targeted preventive and educational interventions, for example through the mass media, are needed.

\section{References}

1. The health consequences of smoking: a report of the Surgeon General. Washington, DC, US Department of Health and Human Services, Centers for Disease Control and Prevention, National Center for Chronic Disease Prevention and Health Promotion, Office on Smoking and Health, 2004.

2. The human cost of tobacco. Passive smoking: doctors speak out on behalf of patients. London, British Medical Association, 2004.

3. Gajalakshmi V et al. Smoking and mortality from tuberculosis and other disease in India: retrospective study of 43000 adult male deaths and 35000 controls. Lancet, 2003, 362:507-15.

4. Crofton J, Simpson D. Tobacco: a global threat, Chapter 6. New York, Macmillan, 2002:43.

5. Fiore $\mathrm{MC}$ et al. Treating tobacco use and dependence. Clinical practice guideline. Rockville, Maryland, US Department of Health and Human Services. Public Health Service, 2000.

6. Students extinguish tobacco investment. Times higher education supplement, 12 November 2004 (Extracted from $\mathrm{ASH}$ daily news, 15 November 2004).

7. Peto R. Smoking and death: the past 40 years and the next 40 . British medical journal, 1994, 309:937-9.

8. Fakhfakh $\mathrm{R}$ et al. Tobacco use in Tunisia: behaviour and awareness. Bulletin of the World Health Organization, 2002, $80: 350-6$

9. Global Youth Tobacco Survey Collaborating Group. Differences in worldwide tobacco use by gender: findings from the Global Youth Tobacco Survey. Journal of school health, 2003, 73, 6:207-15.

10. Mohammad $\mathrm{K}$ et al. Changes observed in the pattern of smoking in Iran during 1991-1999, based on National Health and Disease Surveys. Hakim journal, 2000, 197:290-4.

11. Tobacco or health: a global status report. Geneva, World Health Organization, 1997.

12. Charles WW et al. Tobacco use by youth: a surveillance report from the Global Youth Tobacco Survey project. Bulletin of the World Health Organization, 2000, 78(7):867-80.

13. Yazdani A. Evaluation of factors affecting cigarette addiction in male high school students of Isfahan [MSc thesis]. Tehran, Islamic Republic of Iran, Nursing College of Iran Medical University, 1989.

14. Tessier JF, Nejjari C, Bennani-Othmani M. Smoking in Mediterranean countries: Europe, North Africa and the Middle East. Results from a co-operative study. International journal of tuberculosis and lung disease, 1999, 3:927-37.

15. Ziaee P, Hatamizadeh N, Dolatabadi Sh. Rate of cigarette smoking and the age of first smoking experience among the high school students of Tehran during 19981999. Hakim journal, 2001, 2:78-84.

16. World Health Organization International Consultation on Environmental Tobacco Smoke (ETS) and Child Health, 11-14 January 1999. Consultation report. Geneva, World Health Organization, 1999:6-11 (WHO/NCD/TFI/99.10). 